\title{
Preliminary Study of Population Genetic Diversity of Hyalinoecia tubicola (Polychaeta: Onuphidae) from the North East Coast of Tunisia (Western Mediterranean) using Random Amplified Polymorphic DNA Markers
}

\section{Sana Zaâbi' ${ }^{1}$ Isabelle Metais ${ }^{2}$, Patrick Gillet ${ }^{2}$, Ahmed Afli' ${ }^{1}$ and Moncef Boumaiza ${ }^{3}$}

${ }^{1}$ Laboratoire de Biodiversité et Biotechnologie Marine, Institut National des Sciences et Technologies de la Mer, Salammbô, Tunisia

${ }^{2}$ Equipe de recherche Mer, Molécules, Santé, PRES LUNAM Institut de Biologie et d'Ecologie Appliquée, Angers, France

${ }^{3}$ Unité d'Hydrobiologie Littorale et Limnique, Faculté des Sciences de Bizerte, Tunisia

\begin{abstract}
To evaluate genetic variability within and among Populations of Hyalinoecia tubicola (Müller, 1776), 30 individuals from seven populations were compared using random amplified polymorphic DNA (RAPD) markers. Populations of Hyalinoecia tubicola (Müller 1776) were sampled during the period 2005-2006 from six different sites in the Cap Bon peninsula (North East coast of Tunisia). Genomic DNA of the 25 individuals studied was purified, and genetic analysis was conducted using RAPD primers. Molecular variability into the populations was analyzed using PopGene 1.32 software. One population of Aponuphis bilineata was used as an out group for the study. Results showed that the sampled populations are genetically diverse according to the high value of the gene flow (8.26) and the Nei's genetic index for the total populations (0.2). These preliminary results have important implications for conservation policy.
\end{abstract}

Keywords: Hyalinoecia tubicola; Aponuphis bilineata; Population genetics; Polymorphic DNA; PCR; Cap Bon peninsula

\section{Introduction}

Biodiversity was evaluated for long time by simple species inventories. The measures of intraspecific biodiversity were generally based on individual's morphological analyses by comparison of phenotypic characters. However, molecular approaches based on genetic marker are nowadays extensively used, and are highly informative especially to study population structure. Techniques derived from PCR (Polymerase Chain Reaction) are highly effective in identifying species, varieties or individuals by DNA fingerprinting [1-4]. In this context, the RAPD (Random Amplified Polymorphic DNA) technique [5] is used as it provides numerous genetic markers useful to assess genetic variability and population structures when no DNA sequence data are known on the studied species. RAPD technique was previously used only for several studies on polychaetes, mainly those dealing with molecular phylogeny of some families or species. Struck HT, et al. studied the phylogeny of Eunicida and their presumed relationship to Dinophilidae; showed that monophyly of Clitellata is well-supported by both morphological and molecular data $[2,6]$. RAPD technique was also used to verify the cosmopolitan status of Hesionides arenaria and Stygocapitella subterranea [7], of Ctenodrilus serratus [8], and to assess the genetic variability of Neanthes succinea [9], of Pectinaria koreni [10], and of Alitta succinea [11].

To our knowledge, no genetic data were previously obtained from the polychaete Hyalinoecia tubicola (Müller 1776). This organism is an Onuphidae which has a broad geographic distribution living in oceans all over the world from shallows to $2448 \mathrm{~m}$ depth [12]. Thus, $H$. tubicola is distributed in the western Atlantic [13,14], in the eastern Atlantic [15-17], in Indo-Pacific [16] and in the Mediterranean Sea [18-21]. In Tunisia, H. tubicola was reported in the North [22], in the Bay of Tunis $[23,24]$ and in the Cap Bon Peninsula $[25,26]$ H. tubicola lives in fine and muddy sediments of the circalittoral and bathylittoral zones of the Mediterranean Sea but occurred in coarse substrates of Atlantic coast [27]. According to [28], H. tubicola is a detrital circalittoral species, but rarely found in the bathyal zone. In the present study, $H$. tubicola is among the most abundant polychaete species collected in the circalittoral bottoms of the Cap Bon peninsula (from $40 \mathrm{~m}$ to $60 \mathrm{~m}$ ).

Aponuphis bilineata is also a member of the Onuphidae family. The distribution area of this species seems limited to the North Atlantic [29-32] and the Mediterranean coasts [33-36]. In Tunisia, it was reported in the Gulf of Tunis [37] and, as H. tubicola, in the Cap Bon Peninsula [38]. According to [39], A. bilineata can live in a wide range of sediment as, it has been found in more or less muddy fine sands [4042], compact muds, organic sand [43] or muddy gravel [35].

This paper is the first study assessing the intrapopulation genetic variability and the genetic differentiation level of six populations of Hyalinoecia tubicola from the Cap Bon Peninsula (Western Mediterranean) using the RAPD technique. Living in the same repartition area, A. bilineata was used as an out-group in this study for inter-specific comparison.

\section{Materials and Methods}

\section{Study area}

The study area (Figure 1), located on the north-east coast of Tunisia, covers $300 \mathrm{~km}$ of coastline and is a transition zone between the eastern and western Mediterranean basins. Tunisian marine waters belong to the western and eastern Mediterranean basins. It is in the Strait of Sicily that is the total trade between the two Mediterranean

*Corresponding author: Sana Zaâbi, Laboratoire de Biodiversité et Biotechnologie Marine, Institut National des Sciences et Technologies de la Mer, Salammbô, Tunisia, Tel: +21696663595; Fax + 21671 732622; E-mail: zaabi.sana@yahoo.fr

Received January 16, 2015; Accepted February 16, 2015; Published February 14,2015

Citation: Zaâbi S, Metais I, Gillet P, Afli A, Boumaiza M (2015) Preliminary Study of Population Genetic Diversity of Hyalinoecia tubicola (Polychaeta: Onuphidae) from the North East Coast of Tunisia (Western Mediterranean) using Random Amplified Polymorphic DNA Markers. J Coast Zone Manag 18: 397. doi: 10.4172/24733350.1000397

Copyright: ( 2015 Zaâbi S, et al. This is an open-access article distributed under the terms of the Creative Commons Attribution License, which permits unrestricted use, distribution, and reproduction in any medium, provided the original author and source are credited. 
Citation: Zaâbi S, Metais I, Gillet P, Afli A, Boumaiza M (2015) Preliminary Study of Population Genetic Diversity of Hyalinoecia tubicola (Polychaeta: Onuphidae) from the North East Coast of Tunisia (Western Mediterranean) using Random Amplified Polymorphic DNA Markers. J Coast Zone Manag 18: 397. doi: 10.4172/2473-3350.1000397

Page 2 of 6

basins [44]. Currents are complex due to its geographical position, the morphology of the seabed and wind regime [45].

The salinity and temperature of these waters present seasonal fluctuations and is influenced by the air temperature. The salinity of these waters can reach $38 \%$ and is often subject to the influence of the Atlantic surface water whose maximum occurs in winter and the waters of the eastern basin that seem rise to the surface in the spring and summer.

The depths of stations investigated varied between $45 \mathrm{~m}$ and $60 \mathrm{~m}$. The particle size analysis shows that the sediment ranged from muddy sand to gravel, mainly constituted of muddy sand, fine sand, gravel and rocky substrate (Table 1).

\section{Sampling}

In this study, six populations of Hyalinoecia tubicola (Table 1) were collected from the Cap Bon Peninsula (north east coast of Tunisia) from six sites located in: Sidi Daoud (Mt2), Ras Ed Drek (Mt15 and Mt16), Dar Allouche (21) and Kerkouane (Mt24 and Mt27); and Aponuphis bilineata from one site (Mb37) between Menzel Temim and Menzel Horr, from September 2005 to May 2006. Aboard the R/V Hannibal, a Van Veen grab $\left(0.1 \mathrm{~m}^{2}\right)$ was used on the sites $1-32,15$ and 16 , and a Charcot dredge was used to sample the sites 22, 25, 26 and 37. Samples were washed through a $1-\mathrm{mm}$-mesh sieve and fixed in $7 \%$ sea water formaldehyde for identification. In the laboratory, samples were rinsed in fresh water and preserved in $70 \%$ ethanol. The sorted polychaetes were identified to species and counted.

\section{DNA extraction and PCR amplification}

Genomic DNA was purified from $20 \mathrm{mg}$ of tissue from 5 individuals of each population except for population Mt2 (1 individual) and Mt27 (4 individuals), using the 'DNeasy Blood \& Tissue Kit' (QUIAGEN). Seven random decamers RAPD primers [5] were tested and three primers, IBEA08 (5'GAAACACCCC3'), IBEA09 (5'TGTAGCTGGG3') and IBEA10 (5'AGGGCCGTCT3'), were selected based on their band reproducibility and variability. The amplification solution $(25$ $\mu \mathrm{l})$ contained $50 \mathrm{ng}$ genomic DNA templates, $100 \mu \mathrm{M}$ of each dNTP (Promega), 5 pmol of each primer (MWG Biotech), Green Flexi 1X reaction buffer, $2 \mathrm{mM}$ of $\mathrm{MgCl}_{2}$ and 1 unit of Taq DNA Polymerase (Promega).

PCR was performed in a Mastercycler thermocycler (Eppendorf) as follows: the initial denaturation at $94^{\circ} \mathrm{C}$ for $3 \mathrm{~min}$ was followed by 45 cycles of $30 \mathrm{~s}$ at $94^{\circ} \mathrm{C}, 30 \mathrm{~s}$ at $36^{\circ} \mathrm{C}$, and $1 \mathrm{~min}$ at $72^{\circ} \mathrm{C}$, with a final elongation step at $72^{\circ} \mathrm{C}$ for $10 \mathrm{~min}$. Amplifications replicates were done for each samples.

\section{PCR product migration and visualization}

Fragments generated by PCR amplification were separated by size through electrophoresis on $1.4 \%$ agarose gels buffered with $0.5 \times$ TBE. Bands were visualized by illumination under UV light after staining

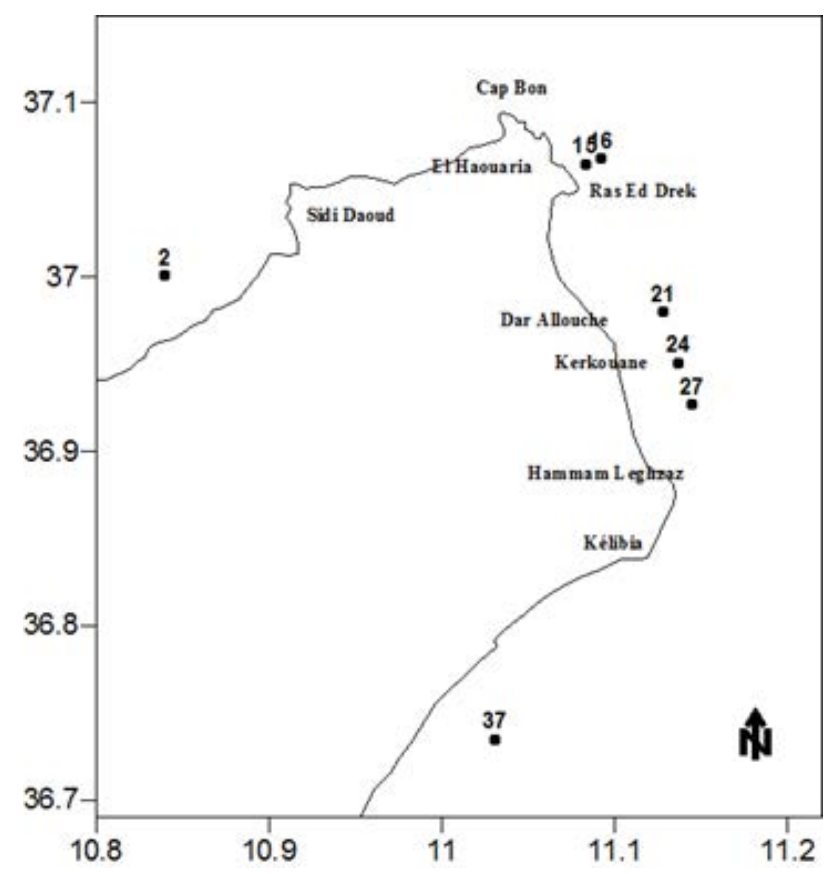

Figure 1: Location of the sampling sites of Hyalinoecia tubicola and Aponuphis bilineata, Cap Bon Peninsula.

\begin{tabular}{|c|c|c|c|c|c|}
\hline Populations & Sites & Depth (m) & Position & Sediment type & Individuals \\
\hline Mt2 & 2 & 45 & $10^{\circ} 50^{\prime} 04^{\prime \prime} / 37^{\circ} 00^{\prime} 07^{\prime \prime}$ & Fine sand & 1 \\
\hline Mt15 & 15 & 50 & $11^{\circ} 05^{\prime} 02^{\prime \prime} / 37^{\circ} 03^{\prime} 55^{\prime \prime}$ & Gravel & 5 \\
\hline Mt16 & 16 & 60 & $11^{\circ} 05^{\prime} 34^{\prime \prime} / 37^{\circ} 04^{\prime} 08^{\prime \prime}$ & Rocky substrate & 5 \\
\hline Mt21 & 22 & 60 & $11^{\circ} 08^{\prime} 43^{\prime \prime} / 36^{\circ} 59^{\prime} 04^{\prime \prime}$ & Gravel & 5 \\
\hline Mt24 & 25 & 60 & $11^{\circ} 09^{\prime} 02^{\prime \prime} / 36^{\circ} 57^{\prime} 25^{\prime \prime}$ & Fine sand & 5 \\
\hline Mt27 & 28 & 60 & $11^{\circ} 10^{\prime} 10^{\prime \prime} / 36^{\circ} 56^{\prime} 09^{\prime \prime}$ & Muddy sand & 4 \\
\hline Mb37 & 37 & 32.5 & $11^{\circ} 01^{\prime} 54^{\prime \prime} / 36^{\circ} 44^{\prime} 09^{\prime \prime}$ & Coarse sand & 5 \\
\hline
\end{tabular}

Table 1: Hyalinoecia tubicola and Aponuphis bilineata populations and main characteristics of sampling sites. 
Citation: Zaâbi S, Metais I, Gillet P, Afli A, Boumaiza M (2015) Preliminary Study of Population Genetic Diversity of Hyalinoecia tubicola (Polychaeta: Onuphidae) from the North East Coast of Tunisia (Western Mediterranean) using Random Amplified Polymorphic DNA Markers. J Coast Zone Manag 18: 397. doi: 10.4172/2473-3350.1000397

with ethidium bromide using a video camera. RAPD fragment size was estimated by comparison with the $1 \mathrm{~kb}$ Plus DNA Ladder.

\section{Genetic analysis of PCR data}

After collecting all the results obtained for the same primer, the bands are numbered according to their location on different gels, and the presence (1) or absence (0) of each band is referenced in a binary matrix for each amplified sample. Data analysis was performed using POPGEN 1.32 software [1].

\section{Results}

\section{RAPD profiling}

On the thirty individuals collected at the Cap Bon Peninsula and further analyzed by RAPD technique, 25 morphologically identical samples (6-30) belong to the species $H$. tubicola (Mt2, Mt15, Mt27, Mt24, Mt21 and Mt16). While one population (Mb37) with five sampled individuals (1-5) belongs to the species A. bilineata and are also morphologically identical.

The three primers (IBEA08, IBEA09 and IBEA10) selected for the study showed a broad affinity for all individual DNA studied and generated a total of 43 suitable and reproducible DNA bands, ranging from 200 to $1800 \mathrm{bp}$. RAPD fingerprinting profiles are shown in Figure 2. The total number of amplified bands generated per primer ranged from 13 (IBEA09) to 16 (IBEA08), with most of them (99\%) being polymorphic (Table 2). RAPD fragment size was estimated by comparison with the DNA Ladder.

Table 3 shows genetic variability parameters obtained within each population based on RAPD data. The highest number of alleles (na)

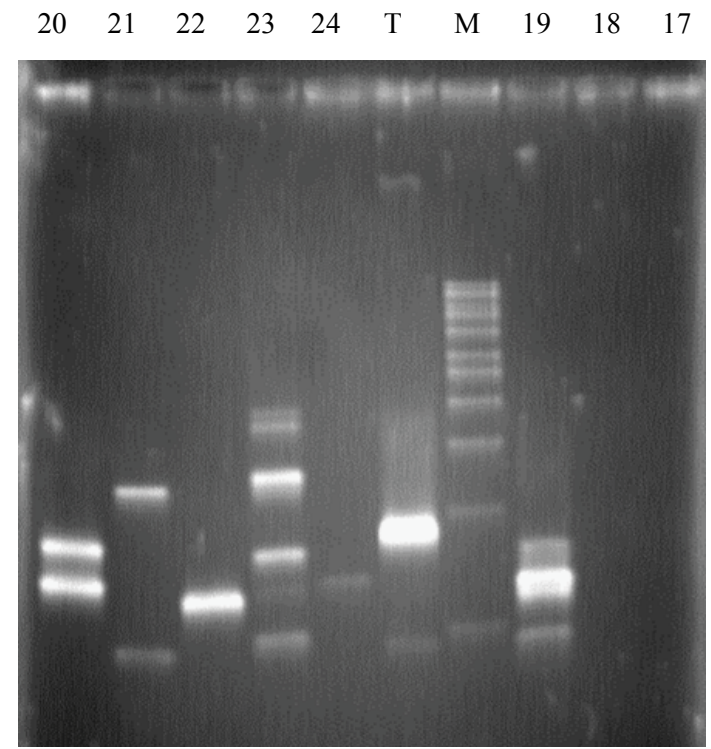

Figure 2: Examples of RAPD profiles for five individuals (20, 21, 22, 23 and 24) of the population Mt21 for the IBEA08 primer.

\begin{tabular}{|c|c|c|c|}
\hline Primers & Sequences $\left.\mathbf{( 5}^{\prime} \mathbf{-} \mathbf{3}^{\prime}\right)$ & NB & Size $\mathbf{( p b )}$ \\
\hline IBEA08 & GAAACACCCC & 20 & $200-1800$ \\
\hline IBEA09 & TGTAGCTGGG & 10 & $200-1100$ \\
\hline IBEA10 & AGGGCCGTCT & 13 & $200-1400$ \\
\hline
\end{tabular}

Table 2: RAPD primers, sizes and their sequences in the study. was observed in the Mb37 population of A. bilineata (1.67) and the lowest in M2 population of $H$. tubicola (1.0). Maximum and minimum number of effective alleles (ne) was observed in Mb37 (1.30) and Mt2 (1.0), respectively. Identified loci showed a high polymorphic level over all the studied populations (99\%). This result indicates the efficiency of the RAPD technique used for the genetic diversity analysis of the studied populations. The highest polymorphism level was found for the single population Mb37 of A. bilineata (67.44\% of polymorphic loci or 29 loci), followed by the population Mt16 of H. tubicola (39.53\% of polymorphic loci, 17 loci), whereas the population Mt2 with only one individual is monomorphic.

The percentage of polymorphic loci (P loci\%), Nei's gene diversity (h) and Shannon's information index (I), calculated for different populations, indicated that the genetic diversity within Mb37 ( $\mathrm{P}$ loci $=67.44 \%, h=0.19$ and $\mathrm{I}=0.30$ ), situated between Menzel Temim and Menzel Horr, showed the highest values, whereas the lowest values were observed for population Mt24 localized across from Kerkouane ( $\mathrm{P}$ loci=20. 93\%, $\mathrm{h}=0.06$ and $\mathrm{I}=0.10$ ). Both populations Mt15 and M16 have close Nei's genetic diversity h values and Shannon's information index I: $0.11,0.10$ and $0.16,0.17$, respectively. The same observation can be done for Mt24 and Mt27. At the populations level, a relatively low value of the diversity coefficient among populations $\mathrm{Gst}=0.057$ was obtained whereas a high value of gene flow $\mathrm{Nm}(8.26)$ was revealed. The average coefficient $\theta$ (Fst) shows that $35 \%$ of the variation is expressed among populations while $65 \%$ of the variability lies within populations (Table 4). While, analysis performed separately for the six populations of $H$. tubicola revealed a relatively high value of Gst (0.60), low value of $\mathrm{Nm}(0.33)$ and low average coefficient $\theta(0.07)$ which indicate that $93 \%$ of the variation is within populations.

Table 6 showed the Nei's genetic identity (above diagonal) and genetic distance (below diagonal) between the different populations based on RAPD data.

The maximum value of the genetic distance was obtained between Mt2 and Mb37 (0.358); the lowest value of genetic distance was obtained between Mt24 and Mt16 (0.016) (Table 5). The matrix of Nei's genetic was used to build an UPGMA based dendrogram (Figure 3). No clear clustering of the individuals from each studied population

\begin{tabular}{|c|c|c|c|c|c|c|c|}
\hline Populations & Individuals & na & ne & $\mathbf{P}$ & $\mathbf{\%} \mathbf{P}$ & he & $\mathbf{I}$ \\
\hline Mt2 & 1 & 1 & 1 & 0 & 0 & 0 & 0 \\
\hline Mt15 & 5 & 1.32 & 1.17 & 14 & 32.56 & 0.11 & 0.16 \\
\hline Mt27 & 4 & 1.21 & 1.13 & 9 & 20.93 & 0.07 & 0.11 \\
\hline Mt24 & 5 & 1.21 & 1.11 & 9 & 20.93 & 0.06 & 0.10 \\
\hline Mt21 & 5 & 1.35 & 1.14 & 15 & 34.88 & 0.09 & 0.15 \\
\hline Mt16 & 5 & 1.39 & 1.15 & 17 & 39.53 & 0.10 & 0.17 \\
\hline Mb37 & 5 & 1.67 & 1.30 & 29 & 67.44 & 0.19 & 0.30 \\
\hline Total population & 30 & 2 & 1.24 & 43 & 100 & 0.17 & 0.29 \\
\hline
\end{tabular}

Table 3: Genetic variability within each population based on RAPD data (na: number of alleles; ne: number of effective allele; $P$ : number of polymorphic markers; $P(\%)$ : percentage polymorphic loci; h: gene diversity; I: Nei's genetic identity, he: mean expected heterozygosity [46]

\begin{tabular}{|c|c|c|c|c|}
\hline & $\mathbf{H t}$ & $\mathbf{G}_{\text {ST }}$ & $\boldsymbol{\theta}$ & $\mathbf{N m}$ \\
\hline Ab and Ht populations & $0.20(0.02)$ & 0.057 & $0.35(0.04)$ & 8.26 \\
\hline $\mathrm{Ht}$ populations & $0.19(0.02)$ & 0.60 & $0.07(0.005)$ & 0.33 \\
\hline
\end{tabular}

Table 4: Analysis of Nei genetic diversity in populations of two species $H$. tubicola and $A$. bilineata in the north-east coast of Tunisia. Ht, total genetic diversity (SD); GST, average coefficient of genetic differentiation of Nei (Nei, 1987); Theta (standard deviation) analogous to FST (Weir \& Cockerham, 1984; Weir, 19901996) and Nm, gene flow [47-49]. 
Citation: Zaâbi S, Metais I, Gillet P, Afli A, Boumaiza M (2015) Preliminary Study of Population Genetic Diversity of Hyalinoecia tubicola (Polychaeta: Onuphidae) from the North East Coast of Tunisia (Western Mediterranean) using Random Amplified Polymorphic DNA Markers. J Coast Zone Manag 18: 397. doi: 10.4172/2473-3350.1000397

Page 4 of 6

\begin{tabular}{|c|c|}
\hline Populations & individual number \\
\hline \multirow{5}{*}{ Mb37 } & 1 \\
\hline & 2 \\
\hline & 3 \\
\hline & 4 \\
\hline & 5 \\
\hline Mt2 & 6 \\
\hline \multirow{5}{*}{ Mt15 } & 7 \\
\hline & 8 \\
\hline & 9 \\
\hline & 10 \\
\hline & 11 \\
\hline \multirow{4}{*}{ Mt27 } & 12 \\
\hline & 13 \\
\hline & 14 \\
\hline & 15 \\
\hline \multirow{5}{*}{ Mt24 } & 16 \\
\hline & 17 \\
\hline & 18 \\
\hline & 19 \\
\hline & 20 \\
\hline \multirow{5}{*}{ Mt21 } & 21 \\
\hline & 22 \\
\hline & 23 \\
\hline & 24 \\
\hline & 25 \\
\hline \multirow{5}{*}{ Mt16 } & 26 \\
\hline & 27 \\
\hline & 28 \\
\hline & 29 \\
\hline & 30 \\
\hline
\end{tabular}

Table 5: Populations and individual's numbers

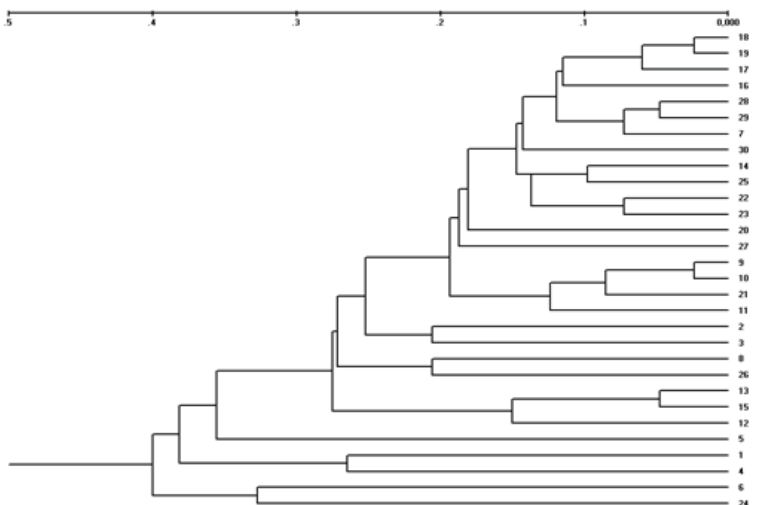

Figure 3: UPGMA dendrogram of 30 individuals from 7 Tunisian populations of H. tubicola and A. bilineata based on RAPD primers.

was observed. The number description of individuals and populations appearing in the dendrogram are shown in Table 5.

\section{Discussion}

\begin{tabular}{|c|c|c|c|c|c|c|c|}
\hline Populations & M37 & M2 & M15 & M27 & M24 & M21 & M16 \\
\hline M37 & & 0.6986 & 0.9401 & 0.9024 & 0.9499 & 0.9647 & 0.9476 \\
\hline M2 & 0.3587 & & 0.7336 & 0.7036 & 0.6482 & 0.7167 & 0.7071 \\
\hline M15 & 0.0617 & 0.3099 & & 0.9235 & 0.9510 & 0.9697 & 0.9944 \\
\hline M27 & 0.1027 & 0.3516 & 0.0796 & & 0.8775 & 0.9102 & 0.9142 \\
\hline M24 & 0.0514 & 0.4335 & 0.0502 & 0.1306 & & 0.9523 & 0.9835 \\
\hline M21 & 0.0360 & 0.3330 & 0.0308 & 0.0941 & 0.0489 & & 0.9760 \\
\hline M16 & 0.0539 & 0.3465 & 0.0056 & 0.0897 & 0.0166 & 0.0243 & \\
\hline
\end{tabular}

Table 6: Nei's genetic identity (above diagonal) and genetic distance (below diagonal) between different populations based on RAPD data

This study showed for the first time that the RAPD-PCR procedure is a sensitive and accurate method applied on the polychaete $H$. tubicola as it requires no preliminary information about the DNA sequence of the studied individuals. Moreover, although the samples were fixed in formalin and preserved for more than one year in $70 \%$ alcohol, the amplification of the genomic DNA of both species $H$. tubicola and A. bilineata by this technique was highly informative and produced a large number of polymorphic markers. The analysis of the RAPD data succeeded in evaluating the genetic diversity among and within the applied H. tubicola. The 6 populations of $H$. tubicola (Mt2, Mt15, Mt27, Mt24, Mt21 and Mt16) collected at the Cap Bon Peninsula and further analyzed by RAPD markers presented samples (individuals 6-30) that cannot be morphologically differentiated. The population Mb37 with five sampled individuals (1-5) belonging to the species $A$. bilineata and also morphologically identical was used as an out group for this analysis. The level of genetic variability detected within the populations of $H$. tubicola was high $(\mathrm{P}=100 \%, \mathrm{He}=0.17$ and $\mathrm{I}=0.29)$, and demonstrated the high capacity of these molecular markers to reveal polymorphism [50]. This could be also explained by the location of the study area, which is a transition zone between eastern and western Mediterranean leading to promote gene exchange between populations. The $A$. bilineata population shows a twofold higher level of intra-specific variability compared to $H$. tubicola populations.

\section{Genetic diversity among populations}

Overall, measures of genetic differentiation by the three parameters $\mathrm{Nm}, \mathrm{GST}$, and $\theta$ indicate a strong genetic divergence between the out-group of $A$. bilineata and $H$. tubicola from the north-east coast of Tunisia associated with high gene flow (8.26). This value reflects an important genes exchange between populations and is higher than that found by [11] $(\mathrm{Nm}=1.12)$ for the Nereididae species Alitta succinea from the Romanian coast of the Black Sea. Although this high value of gene flow, it does not prevent genetic differentiation among populations.

Genetic differentiation between populations is also confirmed by the values of the genetic distance ranging from 0.005 to 0.43 which shows relatively high genetic variability. High differences were detected between Mt2 of H. tubicola and other populations of the same species. On the UPGMA dendrogram, the two individuals 6 and 24 seem to cluster even if they belong to different species and different groups of sampling. These individuals, showing genetic divergence compared to the others individuals, could be cryptic species. This is responded in polychaetes species like Hediste diversicolor [51], Perinereis cultrifera [3], Arenicola defodiens and Arenicola marina [52], Notophyllum [53] and Pygospio elegans [54]. Low genetic distances are observed between populations of the two species A. bilineata and H. tubicola. These relatively low values lead us to think that both species present a common genetic background and may belong to the same genetic group. Indeed, some authors point out that the physical, biological and oceanographic 
Citation: Zaâbi S, Metais I, Gillet P, Afli A, Boumaiza M (2015) Preliminary Study of Population Genetic Diversity of Hyalinoecia tubicola (Polychaeta: Onuphidae) from the North East Coast of Tunisia (Western Mediterranean) using Random Amplified Polymorphic DNA Markers. J Coast Zone Manag 18: 397. doi: 10.4172/2473-3350.1000397

Page 5 of 6

conditions such as temperature, areas of high productivity, food availability and marine currents $[55,56]$ could influence migration and therefore the reproduction exchange between populations of both species. On the other hand, according to the geographical location of populations, type and duration of reproduction, life and also the morphology of individuals vary greatly [3].

In conclusion, this is the first estimation of the genetic diversity of Hyalinoecia tubicola from the Tunisian coast based on RAPD data analysis. Species determination is a difficult work that must now combined morphological and molecular analysis. Most studies to evaluate intra- and inter-specific diversity conducted on polychaetes used nuclear $18 \mathrm{~S}$ and $28 \mathrm{~S}$ genes [57] and mitochondrial COI and $16 \mathrm{~S}$ genes (ref). However, this study demonstrate that the RAPD technique is valuable to determine the level of genetic diversity in $H$. tubicola populations and further work should be done using more specifically COI to extend our knowledge on the potential cryptic individual found in this study.

\section{Acknowledgments}

We would like to thank the personnel of the R/V "HANNIBAL" for their help in sampling and treating benthic samples. We are also grateful to the anonymous reviewers for their reviewing, advising, and critical comments on the manuscript.

\section{References}

1. Yeh FC, Yang R, Boyle T (1999) POPGENE, Version 1.32. Microsoft WindowBased Freeware for Population Genetic Analysis. University of Alberta: Edmonton.

2. Struck HT, Westheide W, Purschke G (2002) Progenesis in Eunicida ("Polychaeta," Annelida) separate evolutionary events. Evidence from molecular data. Molecular Phylogenetics and Evolution 25: 190-199.

3. Rouabah A, Rouabah L (2007) Biodiversité et complexe d'espèces Perinereis cultrifera: un exemple de spéciation. Sciences et Technologies 25: 79-87.

4. Zanol J, Fauchald K, Paulo-Paiva PC (2007). A phylogenetic analysis of the genus Eunice (Eunicidae, polychaete, Annelida). Zoological Journal of the Linnean Society 150: 413-4345.

5. William JGK, Kubelik AR, Livak KJ, Rafalski JA, Tingey SV (1990) DNA polymorphisms amplified by arbitrary primers are useful as genetic markers. Nucleic Acids Research 18: 6531-6535.

6. Struck TH, Halanych M, Purschke G (2005) Dinophilidae (Annelida) is most likely not a progenetic Eunicida: Evidence from $18 \mathrm{~S}$ and 28S rDNA. Molecular Phylogenetics and Evolution 37: 619-623.

7. Schmidt H, Westheide W (2000) Are the meiofaunal polychaetes Hesionides arenaria and Stygocapitella subterranea true cosmopolitan species, results of RAPD-PCR investigations. Zoologica Scripta 29: 17-27.

8. Westheide W, Cordes EH, Krabush M, Müller M (2003) Ctenodrilus serratus (Polychaeta: Ctenodrilidae) is a truly amphi-atlantic meiofauna species Evidence for molecular data. Marine Biology 142: 637-642.

9. Abbiati M, Maltagliati F (1992) Genetic population structure of Neanthes succinea (Polychaeta: Nereididae). Journal of the Marine Biological Association of the United Kingdom 72: 511-517.

10. Jolly MT, Jollivet D, Gentil F, Thiébaut E, Viard F (2005) Sharp genetic break between Atlantic and English Channel populations of the polychaetye Pectinaria koreni, along the north coast of Brittany, France. Heredity 94: 23-32.

11. Gillet P, Surugiu V, Metais I, Mouloud M, Simo P (2011) Preliminary data on population dynamics and genetics of Alitta (= Neanthes) succinea (Polychaeta: Nereididae) from the Romanian coast of the Black Sea. Italian Journal of Zoology, iFirst 1-13.

12. Paxton $\mathrm{H}$ (1986a) Generic revision and relationships of the family Onuphidae (Annelida: Polychaeta). Records of the Australian Museum 38: 1-74.

13. Day J.H. (1973). New Polychaeta from Beaufort, with a key to all species recorded from North Carolina. NOAA Tech. Report. NMFS CIRC-375, Seatle: 140

14. Rullier F, Amoureux L (1979) Campagne de la Calypso au large des cotes atlantiques de l'Amerique du sud (1961-62). Annale de l'Institut océanographique, Paris 55: 149-206.

15. Amoureux L (1973a) Quelques Annélides Polychètes de l'Afrique occidental et équatoriale. Cah. O.R.S.T.O.M. sér. Oceanogr 21: 41-65

16. Intes A, Le Loeuff $P$ (1975) Les Annélides Polychètes de Côte d'Ivoire. I. Polychètes Errantes. Compte rendu systématique. Cah. O.R.S.T.O.M., Sér. Océanogr 13: 267-321.

17. Kunitzer A (1989) The bottom fauna of the central North Sea. ICES. 10.

18. Fauvel $P$ (1957) Contribution à la faune des Annélides Polychètes des côtes d'Israel. II. Bull. Research Council Israel 68: 213-219.

19. Pérès JM (1964) Campagne de la Calypso en mer d'Alboran et dans la baie Ibéro-Marocaine (1958) (suite). Contribution a l'étude des peuplements benthiques du Golfe Ibéro-Marocain. Masson et Cie, Eds. 120 Boulevard SaintGermain, Paris $\left(\mathrm{VI}^{\mathrm{a}}\right)$

20. Amoureux L (1972) Annélides Polychètes du Maroc. Bull. Soc. Sci. Nat. et Phy Du Maroc 52: 47-72.

21. Torres-Gavila FJ (2008) Estudio faunistico, ecologico y ambiental de La fauna de Annélidos poliquetos de substratos sueltos de Las Islas Chafarinas (Mar de Alboran, SW. Méditerraneo). Tesi Doctoral, Valencia: 695.

22. Azzouz A (1973). Les fonds chalutables de la région Nord de la Tunisie. Bulletin de l'Institut Océanographique de Pêche, Salammbô 2: 473-564.

23. Ayari R, Afli A (2003) Bionomie benthique de petit golfe de Tunis. Bulletin Institut National des Sciences et Technologie de la mer, Salammbô 30: 79-90.

24. Ayari R, Afli A (2008) Functional groups to establish the ecological quality of soft benthic fauna within Tunis Bay (Western Mediterranean). Vie et Milieu 58 $67-75$.

25. Zaâbi S, Gillet P, Afli A, Boumaiza M (2009) Biodiversity of polychaetous Annelids from the peninsula of Cap Bon, northeast coast of Tunisia. Zoosymposia 2: 587-600.

26. Zaâbi S, Gillet P, Chambers S, Afli A, Boumaiza M (2012) Inventory and new records of polychaete species from the Cap Bon peninsula, north-east coast of Tunisia, Western Mediterranean sea. Mediterranean Marine Science 13: 36-48.

27. Bellan G (1960) Annélides Polychètes récoltées au cours de son llè campagne méditerranéenne par le "President Theodore-Tissier". Rev. Trav. Inst. Pêches marit 24: 273-292.

28. Bellan G (1961) Contribution à l'étude des Annélides Polychètes de la région de Luc-sur-mer. Bulletin de la Société Linnéenne.

29. Fauvel $P$ (1928) Annélides Polychètes nouvelles du Maroc. Bulletin de la Société Zoologique de France 53: 9-13.

30. Cabioch L, Hardy JP, Rullier F (1968) Inventaire de la Faune Marine de Roscoff. Travaux de la Station Marine de Roscoff N.S 17: 1-95.

31. Amoureux L (1976) Annélides Polychètes récoltés par J. Stirn en 1969 sur les côtes marocaines du détroit de Gibraltar. Cuad. C. Biol 5: 5-33.

32. Campoy A (1982) Fauna d'España. Fauna de Anélidos Poliquetos de la Península Ibérica. Ediciones de la Universidad de Navarra S.A. Serie biológica Pamplona.

33. Pérès JM (1956) Etudes sur le seuil Siculo-Tunisien. In: Resultats scientifiques des campagnes de la Calypso. Annale de l'Institut océanographique, Paris 32 265-304.

34. Rullier F (1963) Les Annélides polychètes du Bosphore, de la Mer de Marmara et de la Mer Noire, en relation avec celles de la Méditerranée. Rapp. Comm. Sist. Mar. Medit 17: 162-260.

35. Bellan G (1964) Contribution à l'étude systématique, bionomique et écologique des Annélides polychètes de la Méditerranée. Recueil des Travaux de la station marine d'Endoume 49: 1-351.

36. Guille A (1970) Les communautés benthiques des substrats meubles du plateau continental au large de Banyuls sur q\& »zMer. C. R. Acad. Sci. Paris 270: 189-192.

37. Cantone G, Fassari G, Brigandi S (1978) Ricerche sui policheti della Tunisia Animalia 5: 51-78.

38. Zaâbi S, Gillet P, Afli A, Boumaiza M (2010) Structure and diversity of polychaetous annelids population along the eastern coast of the Cap Bon 
Citation: Zaâbi S, Metais I, Gillet P, Afli A, Boumaiza M (2015) Preliminary Study of Population Genetic Diversity of Hyalinoecia tubicola (Polychaeta: Onuphidae) from the North East Coast of Tunisia (Western Mediterranean) using Random Amplified Polymorphic DNA Markers. J Coast Zone Manag 18: 397. doi: 10.4172/2473-3350.1000397

Page 6 of 6

Peninsula (north-east coast of Tunisia, western Mediterranean). Marine Biodiversity Records 3, e100 doi: 10.1017/S1755267210000850.

39. Rivain V (1983) Contribution à l'étude dynamique et fonctionnelle des peuplements de sédiments fins du golfe normano-breton. Thèse d'océanographie biologique de l'Université de Paris Vl/station marine du MNHN à Dinard: 166

40. Glémarec M (1965) La faune benthique dans la partie méridionale du Massif Armoricain. Etude préliminaire. Cah. Biol. Mar 6 : 51-66.

41. Amoureux L (1968) Recherches écologiques sur les Annélides Polychètes du genre Nephthys. Extrait des archives de zoologie expérimentale et générale T 109 Fasc 1: 69-77.

42. Retière $C$ (1979) Contribution à la connaissance des peuplements benthiques du golfe normano-breton. Thèse de l'Université de Rennes: 431.

43. Laubier $L$ (1966) Sur quelques Annélides polychètes de la région de Beyrouth Miscellaneous papers in the natural sciences, American University of Beirut 5. 9-23.

44. Morel A (1971) Caractéres hydrologiques des eaux échangées entre le bassin occidental de la Méditerranée. Cahiers océanographiques 23: 329-342.

45. Gaamour A (1999) La Sardinelle ronde (Sardinella aurita, 1847) dans les eaux tunisiennes. Reproduction, croissance et pêche dans la région du Cap Bon. Thèse de Doctorat de l'université de Bretagne occidentale de Brest, France: 246.

46. Nei M (1978) Estimation of average heterozygosity and genetic distance from a small number of individuals. Genetics 89: 583-590.

47. Weir BS, Cockerham CC (1984) Estimating F-statistics for the analysis of population structure. Evolution 38: 1358-1370.

48. Weir BS (1990) Data Analysis: Methods for discrete population genetic data Sunderland, Massachusetts: Sinauer Associates, Inc: 377.
49. Weir BS (1996) Genetic Data Analysis II: Methods for discrete population genetic data. Sunderland, Massachusetts: Sinauer Associates, Inc: 445.

50. Chtourou-Ghorbel N, Marrakchi M, Lauga B, Combes D (2004) Utilisation des marqueurs moléculaires (RFLP et RAPD) pour l'estimation de la variabilité génétique au sein et entre des populations cultivées et spontanées des espèces du genre Lathyrus. CIHEAM-IAMZ: 77-80.

51. Maltagliati F, Massaro L, Cossu P, Castelli A (2006) Morphological differentiation in the ragworm, Hediste diversicolor (Polychaeta, Nereididae), as revealed by variation of paragnath number and distribution. Italian Journal of Zoology 73 $255-262$.

52. Pieternella CL, Dekker R (2010) Pseudo-cryptic species Arenicola defodiens and Arenicola marina (Polychaeta: Arenicolidae) in Wadden Sea, North Sea and Skagerrak: Morphological and molecular variation. Journal of Sea Research 63: 17-23.

53. Nygren A, Eklof J, Pleijel F (2010) Cryptic species of Notophyllum (Polychaeta: Phyllodocidae) in Scandinavian waters. Organisms Diversity and Evolution 10 193-204.

54. Kesäniemi JE, Rawson PD, Lindsay SM, Knott KE (2012) Phylogenetic analysis of cryptic speciation in the polychaete Pygospio elegans. Ecology and Evolution 2: 994-1007. doi: 10.1002/ece3.226

55. Brito-Castillo L, Alcantara-Razo E, Morales-Azpeitia R, Salinas-Zavala CA (2000) Temperaturas del Golfo de California durante mayo y junio de 1996 y su relacion con las capturas de calamar gigante (Dosidicus gigas D'Orbigny, 1835). Cienc. Mar 26: 413-440.

56. Anderson $\mathrm{ClH}$, Rodhouse PG (2001) Life cycles, oceanography and variability: ommastrephid squid in variable environments. Fish. Res 54: 133-143.

57. Bleidorn C, Vogt L, Bartolomaeus T (2003) New insights into polychaete phylogeny (Annelida) inferred from 18S rDNA sequences. Molecular Phylogenetics and Evolution 29: 279-288. 